\title{
РОЗВИТОК ОРФОГРАФІКИ, ГРАФОСТИЛІСТИКИ І ФРАНКОФОНІЇ В УКРАЇНІ
}

\author{
Нарис життя й діяльності \\ До 75-річчя з дня народження професора Крючкова Г. Г.
}

\begin{abstract}
У статті йдеться про справжнього інтелектуала, відомого українського вченого-романіста, талановитого викладача, завідувача кафедри романської філології інституту філології Київського національного університету імені Тараса Шевченка, доктора філологічних наук, професора, заслуженого працівника освіти України Крючкова Георгія Георгійовича. Понад пів століття Крючков Г. Г. удало поєднує викладацьку, наукову, просвітницьку та громадську діяльність. Професор благородно служить філології на ниві освіти, науки й культури, популяризує французьку мову та франкофонні цінності в Україні.

Під керівництвом професора Крючкова Г. Г. захищена не одна кандидатська й докторська дисертації. Його знають і поважають у наукових колах України та за кордоном. Публікації професора часто цитуються, а його думки й ідеї надихають учених на нові наукові звершення та здобутки. Результати досліджень автора привернули увагу французьких, швейцарських, німецьких, нідерландських дослідників, які запропонували розпочати співпрацю 3 іноземними університетами.

У своій викладацькій діяльності Георгій Георгійович завжди приділяв багато уваги методиці викладання іноземних мов. Він був прихильником побудови підручників на комунікативній основі із застосуванням нових методів навчання іноземних мов і розробив власний системно-комунікативний підхід із подальшою іншомовною діяльністю.
\end{abstract}

Крючков Георгій Георгійович постійно перебуває в науковому пошуку, бере участь у наукових конференціях, симпозіумах, круглих столах, колоквіумах, які проводяться в Україні та на теренах інших держав. Він започатковує все нові й нові науково-практичні й творчі проєкти, ініціює проведення франкофонних заходів різних рівнів.

Георгій Георгійович - утілення образу справжнього науковця, викладача 3 великої літери, людини 3 активною суспільною позицією. Усі, кому поталанило з ним працювати, навчатися, спілкуватися тощо, поважають $\mathrm{i}$ цінують його за такі особистісні якості, як порядність та чесність, доброзичливість і тактовність, щирість та доброта. Наукова, педагогічна й громадська діяльність Крючкова Г. Г. відзначені нашою державою й Францією численними нагородами та подяками. На сьогодні Георгій Георгійович Крючков є одним із провідних українських романістів, який виховав декілька поколінь філологів і зробив значний внесок у вітчизняну гуманітаристику.

Ключові слова: орфографіка, романістика, наукова діяльність, викладач, французька мова, громадський діяч.

Крючков Георгій Георгійович - непересічна особистість, вольовий та скромний, мудрий i поміркований, самовідданий у науці та надзвичайно добрий у повсякденному житті. Він присвятив понад пів століття французькій мові та ії популяризації в Україні, його сміливо можна назвати головним Франкофоном країни. Його ім'я й науково-педагогічна діяльність, що нерозривно пов'язані з Київським національним університетом імені Тараса Шевченка, відомі не лише в Україні, але й далеко за ії межами.

Закінчивши в 1970 р. факультет романо-германської філології за спеціальністю «іноземні мови», він не залишив свою Alma mater, а всією своєю багатогранною працею на освітянських і наукових теренах прагнув її подальшого процвітання та визнання у світі.

Крючков Г. Г. - передусім, великий учений-лінгвіст. Він розпочав дослідження французької графіки й орфографії в 1979 р. Спочатку проаналізовано найбільш частотну лексику французької мови («французька елементарна»), потім - «французька фундаментальна» (3000 одиниць) у парадигматиці і синтагматиці. Визначення графічної ініціалі та фіналі дало змогу побудувати первинну матрицю французької орфографії. На цьому матеріалі написано кандидатську дисертацію «Система французької орфографії як єдність парадигматичної та синтагматичної підсистем (на матеріалі «Français fondamental»)» (1980).

Наступний етап наукових пошуків - дослідження всієї графічної форми французької мови (понад 300000 одиниць) уможливив вияв цілісної системи сучасного французького письма, чітке розмежування алфавіт-графіки-орфографії й оформлення нової лінгвістичної науки - орфографіки. Такий підхід дав змогу побудувати загальну матрицю графічної форми 
французької мови, створити трьохвалентний тензор і визначити значущі одиниці сучасного французького письма як у зв'язку зі звуковою формою мови, так і самостійно наявні й уживані в писемній комунікації. По-новому представлено принципи французької орфографії, які розподілено на діахронічні та синхронічні. Матеріали дослідження оформлено в докторській дисертації «Система значущих одиниць сучасного французького письма» (1987).

Теоретичні положення орфографіки набули подальшого розвитку в наукових розвідках докторантів й аспірантів, а саме таких, як Л. В. Сидельникова, О. В. Станіслав, О. В. Косович, Т. Г. Омельченко, О. Д. Федченко, А. В. Новікова, І.В.Ситдикова, В. М. Мазниченко, О. А. Лабенко, Н. В. Бабченко, М. А. Цюпа, В. Р. Калініна-Шамрай.

Ураховуючи динамічну ксенізацію французької мови, відкритість і певний космополітизм французької орфографії, із часом маємо відповісти на питання про створення нової лінгвістичної науки - графостилістики, яка займеться різними варіантами орфограм залежно від графічного стилю, адже саме так з'явилася фоностилістика французької мови.

У своїй викладацькій діяльності Георгій Георгійович завжди приділяв багато уваги та надавав великого значення методиці викладання іноземних мов. Він був прихильником побудови підручників на комунікативній основі із застосуванням нових методів навчання іноземних мов і розробив власний системно-комунікативний підхід із подальшою іншомовною діяльністю. Розпочиналася робота з гіпнопедичного методу для введення уві сні інформації шляхом багаторазової трансляції ввечері й вранці, перед пробудженням, навчальної програми. Подальший розвиток науково-методичної роботи врахував такі загальні принципи, як гуманістична перспектива вивчення мов i сприйняття світових цінностей миру, взаєморозуміння, розвитку й т. ін.; постійне мовне самовдосконалення; спілкування та інтелектуальний розвиток людини; голістичний підхід до викладання мови, що сприяє цілісному розумінню людини, нації, культури. Результати пошуків утілено в низці підручників : «Інтенсивний курс французької мови», Київ, 1984; «Просунутий курс французької мови», Київ, 1989; «Прискорений курс французької мови», Київ (1991-2007); «Елементарний курс французької мови», Київ, 1992; «Французька мова для заочників», Київ, 1993; «Поглиблений курс французької мови», Київ, 1998; «Французька. Мова. Початковий курс», Київ 2009-2017; «Французька мова», Рівень B2, Київ, 2012; «Francophilo», Saarbrücken, 2018.

Співпраця з професором Уілом Кніббелером з Неймегенского католицького університету сприяла врахуванню таких принципів пошуково-творчого підходу в розробці навчальних матеріалів, як пошук, ризик, віра в себе, самостійність, мовна економія, самоконтроль, творчість, емоційність, мотивація до спілкування, взаємодопомога.

Результати розробки методики викладання іноземних мов опубліковані у таких фахових журналах: «Іноземні мови в навчальних закладах» (де Г. Г. Крючков був головою редакційної ради), «Проблеми інтенсивного навчання іноземних мов», «Науково-дослідницький інститут вищої школи», «Проблеми вищої школи».

Георгій Георгійович ніколи не зупинявся на досягнутому, він постійно поглиблював свої знання, удосконалював викладацьку майстерність, проводив наукові дослідження та набував досвіду. У 1977 р. він проходив стажування в Університеті імені Поля Валері Монпельє III (Франція), у 1989 р. стажувався в Сорбонні (Париж, Франція). У 1991 р. читав лекції з теорії письма в Амстердамському університеті, Неймегенському католицькому університеті (Нідерланди), Сорбонні (Франція, Париж); 1991-1994 рр. працював у Національному центрі наукових досліджень (Франція, Париж) [1].

Iз 1994 р. Г. Г. Крючков - експерт Ради Свропи з питань вищої освіти; 1994-2012 pp. голова Комісій МОН України з іноземної філології, з розробки Держстандартів, з іноземних мов тощо; 1994-2002 рр. - експерт ВАК України; 1990-2003 рр. - член вченої ради КНУ імені Тараса Шевченка, член спеціалізованих вчених рад КНУ імені Тараса Шевченка (із 1990 р.), Московського (1990-1996 рр.) і Київського (1990-1999 рр.) лінгвістичних університетів, Університету імені Поля Валері Монпельє III (2012 р.). У 2013 р. - голова журі третього (завершального) туру всеукраїнського конкурсу «Учитель року» у номінації «Французька мова» [2].

Під керівництвом професора Г. Г. Крючкова захищено не одну кандидатську та докторську дисертації. Його знають і поважають у наукових колах України й за кордоном. 
Публікації професора часто цитують, а його думки та ідеї надихають учених на нові наукові звершення та здобутки. Результати досліджень автора привернули увагу французьких, швейцарських, німецьких, нідерландських науковців, які запропонували розпочати співпрацю 3 іноземними університетами.

Георгій Георгійович Крючков постійно перебуває в науковому пошуку, бере участь у наукових конференціях, симпозіумах, круглих столах, колоквіумах, які проводяться в Україні та на теренах інших держав. Він започатковує все нові й нові науково-практичні та творчі проєкти, ініціює проведення франкофонних заходів різних рівнів.

Багато років поспіль Крючков Георгій Георгійович є очільником кафедри романської філології інституту філології Київського національного університету імені Тараса Шевченка. Як завідувач кафедри, дбаючи про іiі імідж, кар'єрний ріст кожного іiі члена, він вибудував у колективі стосунки на глибокій повазі та підтримці. Георгій Георгійович - справжній лідер, беззаперечний авторитет, відповідальний і мудрий керівник.

Із 1989 р. кафедра під керівництвом Крючкова Г. Г. співпрацювала з Національним центром наукових досліджень Франції (підрозділ із питань вивчення історії і структури орфографії під керівництвом Клода Грюаза). Результат співпраці - створення словника синхронних сімей слів української мови, який опубліковано в Парижі на початку 90-х років у трьох томах, а також порівняльне дослідження української, російської й французької мов у рамках програми «Свролексика».

Здійснювалася співпраця з Міжнародним центром наукової культури - Всесвітня лабораторія (Швейцарія), його українським відділенням «Інноваційний технологічний i медичний центр «Київ»», де Г. Г. Крючков керував напрямом «Інтеграція міжнародних комунікативних засобів» (1990-1994).

Життєве кредо Георгія Георгійовича - гасло Res, non verba (Des réalités, non des mots: Cправи, а не слова), яке він неухильно реалізовує, органічно поєднуючи наукову, викладацьку, адміністративну та громадську діяльність.

У 1997 р. він брав участь у спільній конференції Ради Свропи й Північної ради міністрів із питань регіональної співпраці у сфері вищої освіти (Ісландія, Рейк'явік).

У 2001 р. на запрошення співголови Французько-українського форуму Жана-Клода Тріше Г. Г. Крючков брав участь у роботі спільної французько-української комісії з питань культури, науки й техніки.

У 2006 р. із благословення його Святості Папи Бенедикта XVI у Ватикані відбувся міжнародний семінар на тему: «Культурна спадщина та академічні цінності європейського університету і привабливість європейського простору вищої освіти». Г. Г. Крючков керував франкофонною секцією цього семінару.

Щорічні звіти до МОНу й МЗС України про ці заходи мали результатом підписання Урядом України Болонської декларації в Бергені у 2005 р.

Із 2013 р. Г. Г. Крючков сприяв поглибленню співпраці з французьким університетом імені Поля Валері Монпельє III, у якому два викладачі кафедри романської філології захистили докторські дисертації й продовжують працювати в КНУ імені Тараса Шевченка. Французький університет приймає українських студентів 2-го курсу магістратури для подвійного дипломування.

У 2015 р. у КНУ ім. Тараса Шевченка за участі науковців, викладачів та аспірантів двох університетів організовано міжнародну конференцію, присвячену 200-річчю франкомовного українського письменника Яна Потоцького.

Обіймаючи посаду чи то завідувача кафедри романської філології інституту філології, чи то засновника й члена президії «Альянс Францез» в м. Києві (1990), президента-засновника Асоціації викладачів французької мови України (1991-1994), члена адмінради Міжнародної федерації викладачів французької мови (1992-1996), президента Міжнародного комітету Ротарі Інтернешнл «Україна-Франція» (1999-2007), президента-засновника Франкофонної асоціації України (із 2002 року), члена президії асоціації «Україна-Франція» (із 1999 року), експерта Ради Свропи з питань вищої освіти і досліджень (із 1994 року), Георгій Георгійович завжди віддано служить філології на ниві освіти, науки й культури [1]. Уся його діяльність спрямована на 
інтеграцію України до європейського простору та популяризацію таких франкофонних цінностей, як свобода, демократія, право.

Висока фахова репутація та бездоганний авторитет, якими він користується в науковому світі, створили його імідж як справжнього науковця й громадського діяча. Наша держава та Франція високо оцінили таку віддану та багаторічну діяльність Г.Г.Крючкова у сфері викладання й популяризації французької мови та франкофонних пріоритетів в Україні. Він отримав звання «Відмінник освіти України» (2001), «Заслужений працівник освіти України» (2012), нагороджений нагрудним знаком Міністерства освіти і науки України «Петро Могила» (2007), а також є кавалером (2003) й офіцером (2015) ордена «Академічна Гілка» Французької Республіки [1].

Загальна культура, широка ерудиція, глибокі знання, доброзичливість і тактовність цієї особистості вражають; уміння розпалювати інтерес та захоплення предметом викликають заслужену повагу. Георгій Георгійович постійно перебуває в оточенні колег і друзів, $\epsilon$ демократичним у спілкуванні й готовим завжди підтримати та допомогти. На сьогодні Георгій Георгійович Крючков - один із провідних українських романістів, який виховав декілька поколінь філологів і зробив значний внесок у вітчизняну гуманітаристику.

Від себе особисто (О. Станіслав) додам, що для мене Георгій Георгійович - узірець інтелектуальної свободи, Викладач з великої літери, головний український Франкофон та Франкофіл. Вдячна долі за те, що дарувала мені можливість займатися науковими дослідженнями під його керівництвом. Спасибі Вам, дорогий професоре, за розуміння, поради та підтримку, першу професійну оцінку, витримку й толерантність. Безмежно дякую за віру в мене та нашу спільну справу. Нових Вам дослідницьких задумів і звершень, наукових праць та творчих проєктів, злетів і щирих почуттів!

\section{References}

1. Сайт Інституту філології Київського національного університету імені Тараса Шевченка. URL: https://philology.knu.ua/struktura-if/kafedry/roman-fil/spivrobitnyky-roman-fil/kryuchkov/

2. Сайт Міністерства освіти і науки України. URL: https://mon.gov.ua/ua/konkursi-dlya-pedagogiv/konkursuchitel-roku/uchitel-roku-2019/zhuri-2019/francuzka-movazhuri/kryuchkov-georgij-georgijovich

Станислав Ольга, Бритвин Дмитрий. Развитие орфографики, графостилистики и франкофонии в Украине (Очерк жизни и деятельности. К 75-летию со дня рождения профессора Крючкова Г. Г.). В статье рассказывается о настоящем интеллектуале, известном украинском ученом-романисте, талантливом преподавателе, заведующем кафедры романской филологии института филологии Киевского национального университета имени Тараса Шевченко, докторе филологических наук, профессоре, заслуженном работнике образования Украины Крючкове Георгие Георгиевиче. Свыше полувека Г. Г. Крючков удачно сочетает преподавательскую, научную, просветительскую и общественную деятельность. Профессор благородно служит филологии на поприще образования, науки и культуры, популяризирует французский язык и франкофонные ценности в Украине.

Под руководством профессора Крючкова Г. Г. защищена не одна кандидатская и докторская диссертации. Его знают и уважают в научных кругах Украины и за рубежом. Публикации профессора часто цитируются, а его мысли и идеи вдохновляют ученых на новые научные свершения и достижения. Результаты исследований автора привлекли внимание французских, швейцарских, немецких, нидерландских ученых, которые предложили начать сотрудничество с иностранными университетами.

В своей преподавательской деятельности Георгий Георгиевич всегда уделял большое внимание методике преподавания иностранных языков. Он был сторонником построения учебников на коммуникативной основе с применением новых методов обучения иностранным языкам и разработал собственный системнокоммуникативный подход с последующей иноязычной деятельностью.

Крючков Георгий Георгиевич постоянно находится в научном поиске, участвует в научных конференциях, симпозиумах, круглых столах, коллоквиумах, проводимых в Украине и в других государствах. Он начинает все новые и новые научно-практические и творческие проекты, инициирует проведение франкофонных мероприятий различных уровней.

Георгий Георгиевич - воплощение образа настоящего ученого, Преподавателя с большой буквы, человека с активной общественной позицией. Все, кому посчастливилось с ним работать, учиться, общаться, уважают и ценят его за такие личностные качества как порядочность и честность, доброжелательность и тактичность, искренность и доброта. Научная, педагогическая и общественная деятельность Г. Г. Крючкова отмечены нашим государством и Францией многочисленными наградами и благодарностями. На сегодня Георгий Георгиевич Крючков является одним из ведущих украинских романистов, который воспитал несколько поколений филологов и сделал значительный вклад в отечественную гуманитаристику. 
Ключевые слова: орфографика, романистика, научная деятельность, преподаватель, французский язык, общественный деятель.

Stanislav Olha, Brytvin Dmytro. Development of Spelling, Graphical Stylistics and Francophonie in Ukraine Essay on life and activities. To the $\mathbf{7 5}^{\text {th }}$ anniversary of the birth of Professor H. H. Kriuchkov. The article is dedicated to a real intellectual, a famous Ukrainian scientist of romance studies, a talented professor, Head of the Department of Romance Philology of the Institute of Philology of the Taras Shevchenko National University of Kyiv, Doctor of Philology, Professor, Honored Worker of Education of Ukraine Heorhii Kriuchkov. For more than half a century H. Kriuchkov successfully combines teaching, scientific, educational and public activities. The professor nobly serves philology in the field of education, science and culture, promotes the French language and Francophone values in Ukraine.

Under the leadership of Professor Kriuchkov H. defence more than one $\mathrm{PhD}$ and doctoral dissertations. He is known and respected in scientific circles of Ukraine and abroad. The professor's publications are often cited, and his thoughts and ideas inspire scientists to new scientific achievements. The results of the author's research attracted the attention of French, Swiss, German and Dutch researchers, who offered to start cooperation with foreign universities.

In his teaching career, $\mathrm{H}$. Kriuchkov has always paid much attention and importance to the methods of teaching foreign languages. He was a supporter of building textbooks on a communicative basis using new methods of teaching foreign languages and developed his own system-communicative approach with subsequent foreign language activities.

Kriuchkov Heorhii is constantly in scientific research, participates in scientific conferences, symposia, round tables, colloquia, which are held in Ukraine and in other countries. He initiates new and new scientific-practical and creative projects, initiates francophone events of various levels.

Heorhii Kriuchkov is the embodiment of the image of a real scientist, a professor with a capital letter, a person with an active social position. Everyone who is lucky to work, study, communicate, with him, respects and appreciates him for such personal qualities as integrity and honesty, kindness and tact, sincerity and gentleness. Scientific, pedagogical and public activity of Kriuchkov H. is marked by our state and France by numerous awards and gratitude.

Today, Heorhii Kriuchkov is one of the leading Ukrainian scientist of romance studies, who educated several generations of philologists and made a significant contribution to the domestic humanities.

Key words: spelling, Romance philology, teacher, French, public activist.

DOI: https://doi.org/10.32782/2410-0927-2020-13-25

УДК $811.111 ’ 373.23$

Лариса Тараненко, Слизавета Шестопал

\section{ЛІНГВАЛЬНІ ОСОБЛИВОСТІ ВЖИВАННЯ ПРЕЦЕДЕНТНИХ ІМЕН У СУЧАСНІЙ АНГЛОМОВНІЙ ЛІТЕРАТУРІ}

У статті розглянуто особливості вживання прецедентних імен в англійській мові шляхом висвітлення закономірностей їх мовностилістичного вираження у творах сучасної художньої літератури. Аналіз ілюстративного матеріалу здійснено на основі узагальненої класифікації типів і видів прецедентних імен, яка охоплює їх поділ за критерієм належності до певної соціокультурної групи (універсально-прецедентні, національно-прецедентні й соціумно-прецедентні), а також за семантичним критерієм (прецедентні антропоніми та топоніми; термінологічні й полісемічні прецеденти). Серед найчисленніших еталонних тематичних груп прецедентних імен зареєстровано імена історичних осіб, героїв класичних творів і фільмів та міфологеми, які реалізуються в тексті через низку стилістичних фігур, таких як метафора, гіпербола й порівняння. До провідних критеріїв, котрі слугують основою для розрізнення прецедентних феноменів від інших імен, відносимо апелювання до ознак зовнішності осіб або персонажів, рис їхнього характеру або комунікативних ситуацій, через які проявляється знаковість героя або видатної особи. За результатами аналізу з'ясовано, що прецедентні імена як одна з вербальних форм відображення стереотипнометафоричного сприйняття дійсності певною культурною спільнотою людей демонструють тенденцію до розширення свого контекстуального значення та примноження характеристик завдяки здатності формувати ментальні зв'язки між їхнім першоджерелом і новим контекстом. Виконане дослідження ілюстративного матеріалу засвідчило, що прецедентні імена належать до дієвих засобів привернення уваги читача до певної ідеї твору й слугують засобом інтенсифікації конкретних рис та особливостей персонажів художньої літератури XXI ст. Перспективним убачається вивчення питань, пов'язаних із сугестивним й емоційно-прагматичним потенціалами прецедентних імен, а також поглиблення знань про перебіг синергетичних процесів під час їх породження та актуалізації в межах різних лінгвокультур.

Ключові слова: прецедентне ім'я, класифікація, стилістичний прийом, англомовна художня література, функціональне призначення.

Вступ. Сучасному розвитку лінгвістики притаманна зміна векторів іï дослідницьких парадигм, які характеризуються поглибленим вивченням динаміки розвитку мовних i

(C) Тараненко Л., Шестопал С., 2020 